$\mathrm{K}$

STUDIA Z PRAWA WYZNANIOWEGO

Tom $21-2018$

DOI: https://doi.org/10.31743/spw.201

\title{
PRZEŚLADOWANIE RELIGIJNE IRACKICH JEZYDÓW PRZEZ PAŃSTWO ISLAMSKIE. PRZYCZYNY, PRZEBIEG, ODPOWIEDZIALNOŚĆ WSPÓLNOTY MIĘDZYNARODOWEJ ZA UKARANIE SPRAWCÓW
}

Streszczenie

Celem opracowania jest przyjrzenie się prześladowaniu irackich jezydów, jakie dokonało się w ostatnich latach za sprawą tzw. Państwa Islamskiego Iraku i Syrii (ISIS). Przedstawione zostaną religijne i polityczne przyczyny tej zbrodni dokonanej na mniejszości religijnej zamieszkującej iracką prowincję Niniwy. Przeanalizowane zostaną również konsekwencje prawne tych aktów, a także możliwości pociągnięcia do odpowiedzialności sprawców zbrodni. Artykuł składa się z trzech głównych części. Pierwsza zawiera krótki opis historii i teologii jezydyzmu. W drugiej przedstawiono genezę i przebieg prześladowań religijnych jezydów. W trzeciej zaproponowano reakcje prawne, jakie mogłaby podjąć społeczność międzynarodowa aby ukarać sprawców, w szczególności wysunięto propozycję ustanowienia międzynarodowego trybunału karnego.

Słowa kluczowe: wolność religijna; prześladowanie jezydów; ludobójstwo; Państwo Islamskie; ISIS; jezydyzm; odpowiedzialność karna; międzynarodowy trybunał karny.

\section{$* * * * *$}

* Mgr, doktorant w Zakładzie Prawa Kościelnego i Wyznaniowego, Wydział Prawa i Administracji, Uniwersytet Jagielloński, ul. Gołębia 9, 31-007 Kraków, e-mail: rafal.wawrzynczyk@doctoral.uj.edu.pl. ORCID 0000-0002-3733-7104. 


\section{UWAGI WSTĘPNE}

Dramatyczne wydarzenia II wojny światowej, kiedy w sposób niewyobrażalny wcześniej wielokrotnie deptano godność osoby ludzkiej, a masowych morderstw w imię totalitarnej ideologii dokonywano na skalę przemysłową, skłoniły kraje zgromadzone w ramach Organizacji Narodów Zjednoczonych, w tym Irak i Syrię, do jednoznacznego potwierdzenia przyrodzonych i niezbywalnych praw każdego człowieka. Jednym z nich jest prawo do wolności sumienia i wyznania. Efektem wspólnych działań jest Rezolucja Zgromadzenia Ogólnego ONZ 217 A (III) z dnia 10 grudnia 1948 roku, proklamująca Powszechną Deklarację Praw Człowieka. Art. 18 Deklaracji stanowi, że: „[k]ażdy człowiek ma prawo do wolności myśli, sumienia i wyznania; prawo to obejmuje swobodę zmiany wyznania lub wiary oraz swobodę głoszenia swego wyznania lub wiary bądź indywidualnie, bądź wespół z innymi ludźmi, publicznie i prywatnie, poprzez nauczanie, praktykowanie, uprawianie kultu i przestrzeganie obyczajów". Jednocześnie korzystający z tego prawa, „(...) człowiek podlega jedynie takim ograniczeniom, które są ustalone przez prawo wyłącznie w celu zapewnienia odpowiedniego uznania i poszanowania praw i wolności innych, i w celu uczynienia zadość słusznym wymogom moralności, porządku publicznego i powszechnego dobrobytu demokratycznego społeczeństwa" (art. 29 ust. 1). Na gruncie powszechnego prawa międzynarodowego wolność sumienia i wyznania została potwierdzona również w otwartych do podpisu w 1966 roku: Międzynarodowym Pakcie Praw Obywatelskich i Politycznych (art. 18) ${ }^{1}$ oraz Międzynarodowym Pakcie Praw Gospodarczych, Społecznych i Kulturalnych (art. 2 ust. 2)2, tworzących Międzynarodową Kartę Praw Człowieka.

Żeby obraz stanu prawnego był kompletny należy w tym miejscu podnieść, że zapisy związane z prawem do zmiany religii wywołały kontrowersje w krajach arabskich. W późniejszym czasie kraje te opracowały dokumenty międzynarodowe świata arabskiego, takie jak chociażby Kairska Deklaracja Praw Człowieka w Islamie z 5 sierpnia 1990 r., która stwierdza, że podstawowe prawa i wolności są integralną częścią islamu,

\footnotetext{
Dz. U. z 1977 r. Nr 38, poz. 167.

2 Dz. U. z 1977 r. Nr 38, poz. 169.
} 
uznając islam za prawdziwą religię. Deklaracja kairska odrzuca prawo do zmiany religii, co de facto stoi w jawnej sprzeczności z postanowieniami Powszechnej Deklaracji Praw Człowieka z 1948 roku. W przedstawianym opracowaniu pozostawimy tę kwestię na marginesie naszych rozważań, ponieważ będziemy się jedynie zajmować kwestią prawa do swobodnego praktykowania własnej religii, a to prawo znajduje potwierdzenie w art. 18 Deklaracji Praw Człowieka w Islamie ${ }^{3}$.

Po uchwaleniu szeregu aktów deklarujących prawo do swobodnego wyznawania i praktykowania religii jako wrodzonego prawa każdej osoby ludzkiej, również na społeczności międzynarodowej ciąży prawny obowiązek ścigania sprawców zbrodni na tle religijnym. Pociągnięcie ich do odpowiedzialności bez względu na miejsce ich pochodzenia oraz popełnienia przez nich tych przestępstw staje się wymogiem troski o coś, co klasycznym językiem można nazwać ogólnoświatowym dobrem wspólnym.

$\mathrm{Z}$ takim obowiązkiem mamy bezsprzecznie do czynienia w następstwie barbarzyńskich zbrodni dokonywanych przez terrorystów z Państwa Islamskiego Iraku i Syrii (ISIS) w stosunku do mniejszości religijnych i etniczno-religijnych, również w przypadku intersujących nas mieszkańców irackiej prowincji Niniwy. Wśród prześladowanych przez ISIS możemy wskazać chrześcijan różnych wyznań i obrządków, jezydów, turkmenów, mandaitów, szabaków i kakajów ${ }^{4}$. Przedmiotem naszego zainteresowania będą wyznawcy jezydyzmu, którzy przed wkroczeniem islamskich terrorystów do Iraku zamieszkiwali między innymi obszar Niniwy.

Opracowanie będzie się składać z trzech zasadniczych części. Nie zrozumiemy genezy nienawiści do jezydów, jeżeli nie poznamy historii i założeń tej religii. Bowiem to założenia teologiczne jezydyzmu, a raczej ich błędne rozumienie przez osoby spoza tej wspólnoty wyznaniowej, są bezpośrednią przyczyną prześladowań. Zagadnieniu temu poświęcimy pierwszą część artykułu. W części drugiej prześledzimy pokrótce historię prześladowań, które na przestrzeni dziejów spotkały wyznawców jezydyzmu i przyjrzymy się interesującym nas wydarzeniom, przede wszystkim z sierpnia 2014 roku. Część trzecią stanowić będą rozważania, których przedmiotem będzie zbadanie możliwości pociągnięcia do odpowiedzial-

Bar 2003, 62-98; Al-Midani, Cabanettes, Akram 2006, 147-164.

4 Kikoler 2015, 4. 
ności karnej sprawców zbrodni dokonanych na jezydach i roli, jaką w tym procesie może spełnić wspólnota międzynarodowa.

\section{JEZYDYZM - HISTORIA RELIGII, SYSTEM WIERZEŃ I PRAKTYKA WIARY}

Jezydzi, zwani również jazydami (arab. Yazidiyya, kurd. $\hat{E} z d i, \hat{E} z i d i)^{5}$ to stosunkowo nieliczna heterodoksyjna grupa religijna bądź etniczno-religijna, o charakterze nieprozelitycznym, zamieszkująca głównie tereny północnego Iraku, skąd w przeszłości część wyznawców wyemigrowała do Syrii, Turcji ${ }^{6}$ i Iranu. Na początku XX wieku w okresie prześladowań religijnych na terenach Imperium Osmańskiego część społeczności jezydzkiej przeniosła się na tereny Armenii i Gruzji. Druga połowa dwudziestego wieku przyniosła co najmniej trzy kolejne fale migracyjne: w latach osiemdziesiątych z Turcji do Niemiec, na przełomie lat osiemdziesiątych i dziewięćdziesiątych z Iraku do Europy, a także z Armenii i Gruzji na tereny Federacji Rosyjskiej, Ukrainy i dalej w kierunku zachodnim. Małe skupiska jezydów możemy spotkać w Belgii, Holandii, Francji i Stanach Zjednoczonych?

Polska, głównie ze względu na relatywnie niski poziom życia w porównaniu z krajami Europy Zachodniej, nie jest docelowym miejscem emigracji z terenów Bliskiego Wschodu. Wraz z rozwojem gospodarczym naszego kraju sytuacja ta może się jednak zmienić. Również brak znaczącej mniejszości muzułmańskiej w Polsce może w przyszłości zadecydować o atrakcyjności naszego kraju dla nie-muzułmańskich uchodźców i emigrantów z państw islamskich. Według informacji Przedstawicielstwa w Polsce Rządu Regionalnego Kurdystanu, obecnie w naszym kraju przebywa na stałe jedynie kilku wyznawców jezydyzmu, którzy nie tworzą wspólnoty wyznaniowej i nie posiadają żadnego miejsca kultu ${ }^{8}$.

Kolebką religii i najświętszym miejscem jest dolina Lalisz w irackim Kurdystanie, na terenie położonej na północ od Mosulu historycznej

5 Asatrian, Arakelova 2014, vii; Allison 2004.

6 Rodziewicz 2017, 5.

7 Omarkhali 2014, 68.

8 Rząd Regionalny Kurdystanu, Przedstawicielstwo w Polsce, wiadomość e-mail otrzymana przez autora w dniu 19 grudnia 2017 r. 
krainy Szejchanu. Dolina Lalisz miała zostać zesłana przez Boga z nieba w miejscu ulokowania podwalin ziemi ${ }^{9}$. Drugim irackim siedliskiem, a jednocześnie głównym miejscem dramatu jezydów, który rozpoczął się 2014 roku, jest region położonego na wschód od Mosulu Sindżaru w prowincji Niniwy ${ }^{10}$.

Nie jesteśmy niestety w stanie wskazać dokładnej liczby wyznawców jezydyzmu na świecie. Nie było to możliwe nawet przed powstaniem Państwa Islamskiego. Philip G. Kreyenbroek z Uniwersytetu w Getyndze wskazuje, że szacunki wahają się od 200 tyś. do ponad miliona wyznawców. Jego zdaniem jezydów jest 400-650 tyś. Zgodnie z tym wyliczeniem, według stanu na 2009 rok, północny Irak miałoby zamieszkiwać około 200 tyś., Armenię 90 tyś. (choć być może liczbę tę należałoby zmniejszyć o połowę), Gruzję najwyżej 70 tyś., Syrię 2-15 tyś. Nieliczna grupa - około 600 osób - zachować się miała w Turcji. Dodatkowo w Europie zachodniej, głównie w Niemczech oraz na terenach byłego Związku Radzieckiego, do których Kreyenbroek w tym zestawieniu nie zalicza wspomnianych Gruzji i Armenii, ma mieszkać odpowiednio 50 i 60 tyś. Jezydów ${ }^{11}$. Ormiańscy badacze Garnik S. Asatrian i Victoria Arakelova z Uniwersytetu w Erywanie podają następujące dane: Irak - około 200 tyś., Syria - 80-100 tyś., Armenia - 45-50 tyś., Gruzja - 20-25 tyś., Rosja - 10-15 tyś., Europa zachodnia - 40-45 tyś. Łącznie daje to liczbę 400-450 tyś. wyznawców jezydyzmu na świecie ${ }^{12}$.

Większość z jezydów określa siebie jako przynależących do narodu kurdyjskiego. Ich pierwszym językiem jest północno kurdyjski dialekt kurmandżi. Wyjątek stanowią mieszkańscy miejscowości Bahzani i Basziki, a także części regionu Sindżar, dla których pierwszym językiem jest arabski, a dialektem kurmandżi posługują się jedynie w celach religijnych ${ }^{13}$. Trudna historia relacji pomiędzy Kurdami muzułmańskimi a jezydzkimi spowodowała, że część wyznawców jezydyzmu, zwłaszcza osiadłych w diasporze na Zakaukaziu, odżegnuje się od korzeni kurdyjskich i twierdzi, że tworzy

\footnotetext{
Omarkhali 2014, 68.

10 Rodziewicz 2017, 5.

11 Kreyenbroek 2009, 35.

12 Asatrian, Arakelova 2014, vii.

13 Maisel 2008.
} 
osobną grupę etniczną ${ }^{14}$. W ostatnim czasie niektórzy mieszkańcy Sindżaru również zaczęli wypierać się swojej kurdyjskości. Obwiniają podlegające rządowi Autonomicznego Regionu Kurdystanu oddziały peszmergów za to, co ich spotkało ze strony ISIS. Twierdzą, że w pierwszych dniach sierpnia 2014 roku wojska kurdyjskie pozostawiły ich w obliczu śmiertelnego zagrożenia masakrą samymi sobie, bez ostrzeżenia i ochrony ${ }^{15}$.

Nie potrafimy w sposób pewny opisać genezy powstania religii jezydów. Oni sami uznają siebie za pierwszych monoteistów, posiadających system wierzeń i praktyk starszy od islamu i chrześcijaństwa, niezależny od nich. Badacze wskazują, że jezydyzm jest religią o charakterze wybitnie synkretycznym, na którą olbrzymi wpływ wywarły: szyizm, sufizm, chrześcijaństwo, zoroastryzm i religie starożytnego $\operatorname{Iranu}^{16}$. Nie istnieje także konsensus co do pochodzenia nazwy religii. Większość naukowców świata zachodniego uważa, że źródłosłowu nazwy ,jezyd” należy szukać w imieniu umajjadzkiego kalifa Yazida ibn Muawiya, który wedle jezydów miałby być wcieleniem boskiej istoty Sułtana Ezida. Niektórzy natomiast wskazują na staroirańskie yazata, oznaczające „,boską istotę"17. Ciekawą interpretację przedstawiła węgierska badaczka Eszter Spät. Twierdzi ona, że słowo Ézidi ma swoje źródło w zdaniu ez Xwede dam, które znaczy „zostałem stworzony przez Boga"18.

Mówiąc o czynnikach i wydarzeniach, które wpłynęły na powstanie i rozwój jezydyzmu w wersji, jaką znamy dzisiaj, nie możemy pominąć roli żyjącego w XII wieku Szejka Adiego (zm. 1162 r.), potomka umajjadzkiego kalifa Marwana ibn al-Hakam (zm. 685 r.). Zapoczątkował on istnienie bractwa sufickiego Adawiyya o wielkim wpływie na otoczenie religijne gór Kurdystanu, w tym na rozwój jezydyzmu ${ }^{19}$.

Jezydzi wierzą w jednego Boga, którego nazywają Xwedê, Êzdan, rzadziej Heq (Haqq). Przed stworzeniem świata egzoterycznego, gdy ezoteryczny wszechświat był pustką i chaosem Bóg stworzył perłę (dur), w której zamieszkał. Według konkurencyjnej wersji, Bóg powstał w perle jako

\footnotetext{
14 Omarkhali 2014, 67.

15 Kaczorowski 2015, 79-80.

16 Tamże, 37-39.

17 Allison 2004.

18 Za: Kaczorowski 2015, 39.

19 Kreyenbroek 1995, 27-30.
} 
światło i dopiero musiał się z niej wyzwolićc ${ }^{20}$. Następnie stworzył Siedem Boskich Istot, zwanych również Siedmioma Aniołami, czy Siedmioma Tajemnicami (Heft Sur), na których czele stanął Tawusi Melek (Anioł Paw). Bóg manifestuje się jedynie przez swoje hipostazy - Wielką Triadę: Tawusi Meleka, Szejka Adiego i Sułtana Ezida. Siedem Aniołów to pomocnicy Boga w akcie stworzenia świata ezoterycznego. Jak już wspomnieliśmy, jedną z cech charakterystycznych jezydyzmu jest synkretyzm. Oprócz Wielkiej Triady i Siedmiu Aniołów otaczanych kultem jest wiele innych świętych postaci, jak chociażby: Abraham - Ibrahim, Mojżesz - Musa, a także Jezus - Isa. Wszyscy oni posiadają swoje miejsca kultu w Lalisz ${ }^{21}$.

Zgodnie z teologią omawianej religii człowiek - Adam został stworzony przez Boga z czterech żywiołów: wody, ognia, powietrza i ziemi, które są święte i nie mogą być zanieczyszczane ${ }^{22}$. Przy końcu czasu przybędzie natomiast Sherfedin, jeden z pierwszych przywódców religijnych jezydów z rodziny Szejka Adiego. Ma być on Mahdim - mesjaszem, który na czele armii dobra pokona armię szariatu i przywróci stan idealnej egzystencji ${ }^{23}$. Kolejną cechą charakterystyczną religii jest wiara w reinkarnację (metempsychozę), zwaną przez wyznawców ,zmianą koszuli” (kiras gorîn) ${ }^{24}$.

We współczesnym jezydyzmie ważniejsza od ortodoksji jest ortopraksja, której zasady regulują wszystkie aspekty życia. Modlitwa nie ma charakteru obowiązkowego. Niektórzy badacze twierdzą, że wręcz zanika. Do obowiązków praktykującego jezyda należy zaliczyć: uczestnictwo w świętach religijnych, przestrzeganie religijnych zakazów, jałmużnę i pielgrzymki ${ }^{25}$. Społeczność ma strukturę kastową składającą się z trzech zasadniczych grup: szejków, pirów i miridów. Do miridów, którzy tworzą kastę ludzi świeckich (uczniów), należy dziewięćdziesiąt pięć procent je$z_{\text {dó }}{ }^{26}$. Pirowie i szejkowie spełniają funkcje religijne, a podział na te grupy ma zasadniczo charakter historyczny. Pierwotnie funkcje religijne pełniła jedynie grupa pirów, a szejkowie zostali ustanowieni wraz z przy-

\footnotetext{
20 Kaczorowski 2015, 44.

21 Tamże, 47-51

22 Omarkhali 2014, 68.

23 Kreyenbroek 2005, 368 .

24 Omarkhali 2014, 69.

25 Kaczorowski 2015, 61.

26 Omarkhali 2014, 69.
} 
byciem do Lalisz szejka Adiego ${ }^{27}$. Przynależność do danej kasty określa urodzenie $\mathrm{w}$ niej, a przejścia pomiędzy nimi są niedopuszczalne ${ }^{28}$. Ze względu na ruchy migracyjne wypełnienie powyższych wymogów staje się coraz trudniejsze, zwłaszcza wśród małych skupisk jezydów rozsianych po całym świecie ${ }^{29}$.

Głową społeczności jezydów jest książe Szejchanu (Mir), który dzierży tytuł Namiestnika Szejka Adiego i Anioła Pawia. Jego siedziba znajduje się w Ba'adre nieopodal Lalisz. Wywodzi się z rodziny związanej z szejkami Qatani. Mirowie do XVIII wieku byli również oficjalnymi przywódcami politycznymi w Szejchanie. Książę dzierży najwyższą władzę świecką i duchowną. Drugą osobą w społeczności jest Baba Szejk („Ojciec Szejków”), pochodzący zawsze z grupy szejków Samsani ${ }^{30}$.

Przedstawiona powyżej ogólna charakterystyka jezydyzmu nie pozostawia wątpliwości co do jej monoteistycznego charakteru. Cześć oddawana innym bytom, jak członkowie Wielkiej Triady i Sedem Aniołów, nie przeczy powyższej tezie. Należy zatem rozważyć, skąd posądzenia jezydów o politeizm, a co jeszcze bardziej brzemienne w skutkach, o czczenie diabła. Nie ulega wątpliwości, że olbrzymie zainteresowanie jezydyzmem w XX wieku wyrosło właśnie z tego ostatniego stereotypu ${ }^{31}$. Taki stosunek do jezydów nie jest jednak jedynie efektem bujnej wyobraźni zachodnich badaczy i podróżników. Wyobrażenie Anioła Pawia jako inkarnacji diabła, jednoznacznie złego anioła ciemności, źródła ludzkich nieszczęść jest powszechne wśród mieszkańców północnego Iraku, szczególnie wśród wyznawców islamu, i wielokrotnie było pretekstem do prześladowań.

Dla samych jezydów postać Tawusi Meleka ma zupełnie inny charakter, a niezrozumienie subtelności ich religii wynika najczęściej z przyjęcia muzułmańskiej lub chrześcijańskiej perspektywy, która wytworzyła legendę o rzekomym powstaniu ze śliny diabła mitycznego plemienia zamieszkującego góry Kurdystanu ${ }^{32}$. Jak wskazaliśmy powyżej, olbrzymi wpływ na wierzenia jezydów miały poglądy sufickie. Wedle nich szatan jest po-

\footnotetext{
27 Kaczorowski 2015, 55.

28 Allison 2004.

29 Omarkhali 2014, 69.

30 Kreyenbroek 1995, 125-137.

31 Allison 2004.

32 Asatrian, Arakelova 2014, 20.
} 
stacią bezgranicznie oddaną Bogu - swemu stwórcy i wszystko co robi jest wypełnieniem jego woli. Tawusi Melek jest jednocześnie dobry i zły. Za jego przyczyną ludzie musieli opuścić raj, ale jego działanie nie było sprzeczne z wolą Boga, ale wręcz przeciwnie - było jej wypełnieniem. Anioł Paw, utożsamiany $\mathrm{z}$ aniołem Azazelem, miał w wyniku nieposłuszeństwa Bogu stać się Iblisem i zostać wygnany z raju razem z Adamem. Było to spełnienie pragnienia Stwórcy, którym był upadek Azazela i Adama. Azazel był jedynie narzędziem boskiej opatrzności, stąd jego wina powinna zostać wybaczona i wedle jezydów została. Jedna z wersji tego mitu, którą na początku XX wieku usłyszał w irackim Tiflis oficer angielskiego wywiadu, Edward Soane, mówi, że Azazel (Iblis, Anioł Paw) po swoim czynie wypłakał siedem naczyń łez, którymi ugasił siedem piekieł i po siedmiu tysiącach lat wygnania mógł powrócić do nieba ${ }^{33}$.

\section{PRZEŚLADOWANIE}

Endogamiczność, powszechne przestrzeganie tabu religijnego i brak źródeł pisanych powodował w historii i w dalszym ciągu powoduje błędne rozumienie jezydyzmu przez nie-wyznawców, co w rezultacie skutkuje nietolerancją i prześladowaniem wyznawców Anioła Pawia. Znaczna część muzułmanów uznaje jezydów za bałwochwalców.

Analizując przyczyny prześladowań mniejszości religijnych w państwach muzułmańskich należy przede wszystkim wskazać, że osoby nie wyznające islamu traktowane są jak obywatele drugiej bądź trzeciej kategorii. Dwie podstawowe nierówności wynikające z szariatu to: nierówność kobiet i mężczyzn, a także muzułmanów i nie-muzułamanów. Trzecią kategorią, która w kulturze państw islamskich ma już jedynie aspekt historyczny, było rozróżnienie na niewolnika i człowieka wolnego ${ }^{34}$. Zgodnie z tą wizją świata ludzkość dzieli się na trzy kategorie: dar al-islam - dom pokoju, dar al-sulh - dom ochrony i dar al-harb - dom wojny. Dom pokoju zamieszkują muzułmanie, którzy posiadają pełnię praw ${ }^{35}$.

\footnotetext{
33 Tamże, 26-29.

34 Samir, Paolucci, Eid 2004, 55.

35 Tamże, 117.
} 
Dom ochrony tworzą tzw. „ludzie Księgi” (ahl al-kitab), czyli chrześcijanie i żydzi, którzy jako dzieci Abrahama pod pewnymi warunkami mogą żyć w społeczeństwie muzułmańskim w pokoju i praktykować swoją religię ${ }^{36}$. Niektórzy autorzy zaliczają do tego grona dodatkowo zoroastrian, buddystów i hinduistów, którzy pomimo tego, że nie są „ludźmi Księgi”, to jednak nie są politeistami, dlatego również podlegają ochronie ${ }^{37}$. Według muzułmanów jezydzi należą do trzeciej kategorii - domu wojny i zgodnie z tradycyjnym podejściem powinni zostać zwalczani jako błędnowiercy i politeiści (kafirun lub kuffar), a ich jedynym ratunkiem może być konwersja na islam ${ }^{38}$. Wskazana zasada jest najczęściej przywoływana jako uzasadnienie prześladowań, które towarzyszą jezydom od początku ich życia w świecie islamu.

W swojej historii byli oni prześladowani przez religijnych sunnitów, zarówno arabów jak i Kurdów, przedstawicieli Imperium Osmańskiego, Turków, Rosjan, Brytyjczyków i rządzących z partii Baas ${ }^{39}$. Sebastian Maisel z amerykańskiego Uniwersytetu Stanowego Grand Valley przytacza jezydzki hymn religijny, który wspomina okoliczności siedemdziesięciu dwóch historii religijnego ucisku ${ }^{40}$. Przypadek tzw. Państwa Islamskiego to przypadek siedemdziesiąty trzeci.

W najnowszej historii możemy wskazać na akcję przymusowych przesiedleń i arabizacji ze strony irackiego reżimu w latach siedemdziesiątych i osiemdziesiątych XX wieku, a także na szereg aktów agresji i nietolerancji po obaleniu Saddama Husajna. Do najtragiczniejszych zaliczyć należy: zabójstwo 23 jezydzkich pasażerów autobusu w okolicach Mosulu (kwiecień 2007), atak terrorystyczny w dwóch wioskach w Górach Sindżaru, w wyniku którego śmierć poniosło 350 osób (sierpień 2007), dwa zamachy bombowe w mieście Sindżar - 21 ofiar śmiertelnych (sierpień 2009). Natomiast w styczniu 2013 roku jezydzki student Uniwersytetu w Mosulu otrzymał ultimatum: albo opuści uniwersytet, albo zginie. W następstwie tysiąc studentów zrezygnowało $\mathrm{z}$ dalszej edukacji ${ }^{41}$.

\footnotetext{
36 Thoraval 2002, 166-167.

37 Bar 2003, 115.

38 Samir, Paolucci, Eid 2004, 117.

39 Maisel 2008, 3; Maisel 2014.

40 Maisel 2014.

41 Maisel 2008, 1, 4; Kikoler 2015, 9.
} 
Prawdziwa gehenna spotkała jednak sindżarskich jezydów ze strony Państwa Islamskiego. Pełna nazwa tej organizacji w języku arabskim brzmi: Ad-Dbaula al-Islamija fi-l-Irak wa-Sz-Szam. Asz-Szam można tłumaczyć jako Syria lub Lewant. Stąd pełna nazwa polska to Państwo Islamskie Iraku i Syrii lub Państwo Islamskie Iraku i Lewantu (ang. Islamic State of Iraq and the Levant - ISIL, Islamic State of Iraq and Syria - ISIS) ${ }^{42}$. ISIS można określić mianem „hybrydowej struktury terrorystycznej" łączącej w sobie cechy państwa, organizacji terrorystycznej (sieci organizacji terrorystycznych), czy grupy przestępczej o charakterze zbrojnym. Wprawdzie nie jest państwem w rozumieniu prawa międzynarodowego - nie spełnia bowiem wymogu tzw. „zewnętrznej” suwerenności - to jednak posiada zespół cech charakterystycznych dla organizmu państwowego: kontrolowane terytorium, system sprawowania władzy oraz podlegającą władzy ludnośćc ${ }^{3}$. W 2013 roku organizacja ta podporządkowała sobie terytorium centralnej i wschodniej Syrii, a w 2014 roku niemal połowę terytorium Iraku - prowincje Niniwy, Al-Anbar i Salah ad-Din. Na jej czele stanął Abu Bakr al-Baghdadi, który uzurpował sobie tytuły kalifa i imama ${ }^{44}$. W krótkim czasie dzięki stworzeniu sprawnej administracji, wykorzystaniu nowych mediów, dużym możliwościom finansowym, skanalizowaniu rozczarowania sunnickiej mniejszości Iraku i wykorzystaniu ideologii dżihadu w interpretacji takfirskiej, al-Baghdadiemu udało się stworzyć pierwszy nowożytny muzułmański system totalitarny ${ }^{45}$.

Takfiryzm Państwa Islamskiego skierowany jest przeciwko mniejszościom nie sunnickim - przede wszystkim chrześcijanom. Jest to nurt religijno-polityczny postulujący powrót do islamu pierwotnego i stosowanie legalnej przemocy wobec kuffur - ,niewiernych”. Powstał w VII w., a jego odrodzenie obserwujemy od końca lat 70-tych XX wieku. Zgodnie z zasadami szariatu chrześcijańscy mieszkańcy terenów zajętych przez ISIS mieli do wyboru albo przyjęcie islamu, albo zachowanie własnej wiary przy uznaniu zwierzchności islamu i płaceniu dżizji - podatku pogłównego w wysokości 60 dolarów amerykańskich od osoby miesięcznie. W innym

42 Bania 2016, 20.

43 Wojciechowski 2016, 143-144.

44 Bania 2016, 20.

45 Zob. Hanne, Flichy de la Neuville 2015, 47-107. 
wypadku musieli w ciągu dwudziestu czterech godzin opuścić dom lub czekała ich śmierć ${ }^{46}$. Jezydzi, którzy nie są uznawani za „ludzi Księgi”, nie mieli nawet takiego wyboru.

Przebieg i skala działań Państwa Islamskiego przeciwko mniejszości jezydzkiej w Iraku i Syrii zostały opisane w dwóch raportach ONZ: raporcie Biura Wysokiego Komisarza ONZ ds. Praw Człowieka z dnia 13 marca 2015 roku o sytuacji przestrzegania praw człowieka $w$ Iraku $w$ świetle nadużyć dokonywanych przez tzw. Państwo Islamskie w Iraku i Lewancie $i$ grupy powiazane (A/HRC/28/18, United Nations High Commissioner for Human Rights 2015) oraz raportu Rady Praw Człowieka ONZ z dnia 15 czerwca 2016 roku „Przyszli, aby zniszczyc’”. Zbrodnie ISIS przeciwko jezydom (A/HRC/32/CRP.2, Human Rights Council 2016).

Rankiem 3 sierpnia 2014 roku kilkuset bojowników Państwa Islamskiego zaatakowało region Sindżaru od wschodu, od strony Mosulu i Tal Afar w Iraku oraz od zachodu, od strony Asz-Szaddady i Tall Hamis w Syrii. Nie napotkali prawie żadnego oporu. Broniący do tej pory tego regionu kurdyjscy peszmergowie wycofali się przed zbliżającą się ofensywą, pozostawiając mieszkańców Sindżaru bez obrony. Decyzja o wycofaniu wojsk kurdyjskich nie została wcześniej zakomunikowana ludności miejscowej, co wprowadziło dodatkowy element zaskoczenia potęgujący chaos. W swoich działaniach bojownicy ISIS skupili się przede wszystkim na wyłapywaniu jezydów, którzy nie zdołali uciec przed okrążeniem w kierunku miasta Dahuk na północy. Kilkadziesiąt tysięcy osób, mężczyzn, kobiet i dzieci, zostało oblężonych w rejonie góry Sindżar bez jedzenia i wody w temperaturze przekraczającej pięćdziesiąt stopni Celsjusza. W dniu 7 sierpnia na prośbę rządu Iraku wojska amerykańskie, brytyjskie, australijskie i irackie rozpoczęły zrzuty zaopatrzenia dla umierających z wycieńczenia. Do czasu otwarcia przez kurdyjską milicję - Powszechne Jednostki Ochrony (YPG) - korytarza ewakuacyjnego do Syrii na górze Sindżar zmarło kilkaset osób.

Jezydzi, którym nie udało się opuścić swoich wiosek, zostali pojmani przez bojowników Państwa Islamskiego. Mężczyźni zostali oddzieleni od kobiet i chłopców przed okresem dojrzewania (zasadniczo stosowano kryterium wieku - 12 lat). Kilka tysięcy osób zostało uprowadzonych na tereny opanowane przez ISIS w Syrii. Dysponujemy jedynie danymi szacunkowymi.

46 Tamże, 80-81. 
Podanie konkretnej liczby jest w tym momencie niemożliwe. Akcji tej towarzyszyły masowe mordy przede wszystkim mężczyzn, którzy odmówili konwersji na islam. Do najbardziej drastycznych przykładów możemy zaliczyć zamordowanie co najmniej osiemdziesięciu mężczyzn w wiosce Kani oraz czystkę we wsi Koczo - śmierć poniosło co najmniej siedmiuset mężczyzn ${ }^{47}$.

W wyniku powyższych działań:

- Mężczyźni i chłopcy w wieku powyżej dwunastu lat, którzy nie przeszli na islam lub przy których znaleziono broń, zostali zamordowani - często na oczach kobiet i dzieci. Pozostali zostali uwięzieni i uprowadzeni, czasami wraz z rodzinami, w rejon miasta Tal Afar, gdzie wykonywali prace przymusowe na rzecz ISIS. Dodatkowo, podlegali kontroli wykonywania muzułmańskich praktyk religijnych.

- Kobiety zamężne zostały oddzielone od niezamężnych i dziewcząt w wieku od dziewięciu lat. Niezamężne kobiety i dziewczynki od dziewiątego roku życia zostały w zdecydowanej większości przypadków zniewolone (otwarcie używano terminu „,niewolnica”), a następnie oddane bojownikom lub wywiezione do Syrii, gdzie były sprzedawane na targach niewolników, niektóre kilkukrotnie. Pracowały przymusowo jako pomoce domowe lub ,niewolnice seksualne”.

- Dzieci pozostawały pod opieką matek. Często dzieci wraz z matkami były sprzedawane na targach niewolników. Były zakładnikami pełniącymi rolę środka do dyscyplinowania matek. Zanotowano liczne przypadki wykorzystywania seksualnego dzieci i innych form brutalnego traktowania. Dziewczynki po osiągnięciu wieku lat dziewięciu były sprzedawane, a chłopcy od lat siedmiu trafiali do obozów szkolenia bojowników ISIS.

- W całym regionie Sindżaru zniszczono jezydzkie świątynie i miejsca kultu, a także domy prywatne osób przynależących do tej religii ${ }^{48}$.

Nie ulega najmniejszej wątpliwości, że przemoc której doświadczyli jezydzi była motywowana morderczą ideologią religijną, której celem była całkowita likwidacja tej religii na terenach opanowanych przez Państwo Islamskie. W oficjalnym magazynie propagandowym ISIS - Dabiq, czytamy: „Podczas podboju regionu Sindżar w wilajacie Niniwy, Państwo Islamskie

47 Za: United Nations High Commissioner for Human Rights 2015, 6-8.

48 Za: Human Rights Council 2016, 8-19. 
napotkało społeczność jezydów, pogańską mniejszość od wieków zamieszkującą regiony Iraku i Lewantu. Ich ciągła obecność, aż do dnia dzisiejszego, to kwestia, z którą musi się zmierzyć każdy muzułmanin, ponieważ będzie o to zapytany podczas Dnia Sądu, wziąwszy pod uwagę, że od ujawnienia przez Allaha ayat as-sayf (wersetu miecza) upłynęło ponad 1400 lat"49. „Werset miecza” odnajdujemy w surze IX Koranu: „A kiedy miną święte miesiące, / wtedy zabijajcie bałwochwalców, / tam gdzie ich znajdziecie; / chwytajcie ich, oblegajcie / i przygotujcie dla nich wszelkie zasadzki! / Ale jeśli oni się nawrócą / i będą odprawiać modlitwę, / i dawać jałmużnę, / to dajcie im wolną drogę. / Zaprawdę, Bóg jest przebaczający, litościwy!"50.

\section{ODPOWIEDZIALNOŚĆ KARNA SPRAWCÓW}

Opisane w poprzedniej części działania wypełniają znamiona czynów określanych przez prawo międzynarodowe jako zbrodnie ludobójstwa, zbrodnie przeciwko ludzkości i zbrodnie wojenne. Nie wdając się w spory metodologiczne przyjmijmy, że zbrodnia ludobójstwa stanowi osobny typ zbrodni międzynarodowej w stosunku do zbrodni przeciwko ludzkości ${ }^{51}$. Zarówno Irak jak i Syryjska Republika Islamska są stronami Konwencji w sprawie zapobiegania i karania zbrodni ludobójstwa z dnia 9 grudnia 1948 r. ${ }^{52}$ Nie przystąpiły wprawdzie do Konwencji o niestosowaniu przedawnienia wobec zbrodni wojennych i zbrodni przeciw ludzkości z 26 listopada 1968 r. ${ }^{53}$, jednakże wydaje się, że fakt ten nie ma aż takiej doniosłości. Oba kraje są natomiast stronami Konwencji genewskich z 1949 r., w tym IV Konwencji genewskiej o ochronie osób cywilnych podczas wojny (Confédération suisse. Département fédéral des affaires étrangères). Współcześnie w prawie międzynarodowym uznaje się powszechnie, że normy chroniące podstawowe prawa człowieka, a taki katalog norm znajduje się właśnie w obszarze naszego zainteresowania, mają charakter ius

\footnotetext{
49 Dabiq 2014, 14.

50 Koran 1986, IX, 5.

51 Izydorczyk 2008, 117.

52 Dz. U. z 1952 r. Nr 2, poz. 9.

53 Dz. U. z 1970 r. Nr 26, poz. 208.
} 
cogens i obowiązują erga omnes. Wywodzone są one bezpośrednio z prawa zwyczajowego ${ }^{54}$. Irak w swojej praktyce penalnej stosował już te normy w związku z działalnością Irackiego Trybunału Nadzwyczajnego powołanego w grudniu 2003 roku dla rozstrzygnięcia naruszeń prawa międzynarodowego i krajowego przez członków rządzącej Irakiem partii Baas ${ }^{55}$.

Z perspektywy prawa wyznaniowego szczególnie interesującą jest kwestia wypełnienia przez sprawców prześladowań jezydów znamienia zbrodni ludobójstwa w postaci zamiaru zniszczenia grupy religijnej. Zgodnie $\mathrm{z}$ treścią art. II Konwencji w sprawie zapobiegania i karania zbrodni ludobójstwa, ludobójstwem jest między innymi zabójstwo, stworzenie warunków dla celowego fizycznego wyniszczenia, czy przymusowe przekazywanie dzieci członków grupy do innej grupy „,...) w zamiarze zniszczenia w całości lub w części grup (...) religijnych, jako takich”. Powtórzenie tego zapisu znajdziemy w art. 6 Rzymskiego Statutu Międzynarodowego Trybunału Karnego z 17 lipca 1998 r. ${ }^{56}$, a także w art. 11 Statutu Irackiego Trybunału Nadzwyczajnego. Wskazane w poprzedniej części opracowania działania polegające na:

(1) masowych zabójstwach jezydów, którzy nie chcieli przejść na islam głównie mężczyzn;

(2) wzięciu w niewolę kobiet i dzieci, a następnie przekazanie ich pod kuratelę bojowników ISIS, których zachowanie charakteryzowało się wyjątkową brutalnością;

(3) odbieraniu matkom dzieci, a to wszystko w celu wypełnienia motywowanego ideologicznie zobowiązania wynikającego z „wersetu miecza”;

wydają się wypełniać zakreślone znamiona ludobójstwa na tle religijnym. Oprócz znamion zbrodni ludobójstwa na motywację religijną sprawców wskazuje opis znamion zbrodni przeciwko ludzkości, polegającej na prześladowaniu jakiejkolwiek możliwej do zidentyfikowania grupy lub zbiorowości z powodów religijnych poprzez popełnienie czynu uznawanego za zbrodnię międzynarodową (art. 7 ust. 1h Rzymskiego Statutu Międzynarodowego Trybunału Karnego, art. 12 ust. 1H Statutu Irackiego Trybunału Nadzwyczajnego).

\footnotetext{
54 Królikowski 2011, 77; Królikowski 2008,76-80.

55 Na ten temat zob. Bałon 2004, 1089-1091; Al-Waqa'i Al-Iraqiya 2005.

56 Dz. U. z 2003 r. Nr 78, poz. 708.
} 
Obowiązek osądzenia zbrodni wymierzonych w mniejszości religijne w tym interesującą nas iracką społeczność jezydów spoczywa w pierwszym rzędzie na władzach Iraku i Syrii, a z uwzględnieniem przytaczanej już zasady komplementarności na społeczności międzynarodowej. Irak, jako kraj pochodzenia ofiar, próbuje się wywiązać z tego zadania. Na wniosek jego władz Rada Bezpieczeństwa ONZ w dniu 21 września 2017 roku wydała rezolucję S/RES/2379 ustanawiającą grupę śledczą, której zadaniem jest zbieranie, zabezpieczanie i przechowywanie dowodów świadczących o popełnianiu przez bojowników Państwa Islamskiego w Iraku zbrodni ludobójstwa, zbrodni przeciwko ludzkości i zbrodni wojennych. Grupa ta ma działać z poszanowaniem suwerenności i jurysdykcji prawnej Iraku. Na chwilę obecną podstawowymi aktami prawno-karnymi do rozstrzygania tych praw są: na szczeblu federalnym - Prawo antyterrorystyczne nr 13 z 2005 roku (Vertic b.d.) oraz Kodeks karny nr 111 z 1969 roku (Refworld b.d.), a w Regionie Kurdystanu - Prawo antyterrorystyczne Regionu Irackiego Kurdystanu nr 3 z 2006 roku, Prawo karzące posiadanie, wytwarzanie i wykorzystywanie materiałów wybuchowych $\mathrm{nr} 8$ z 1992 roku (Human Right Watch 2017), a także federalny Kodeks karny, z ograniczeniami wynikającymi z postanowień Dekretu ustanawiającego niezależność legislacyjną od Bagdadu, nr 11 z 1992 roku (The University of Utah. S. J. Quinney College of Law b.d.).

Wydaje się jednak, że ani Irak, ani Syria nie są przygotowane na sprostanie zadaniu osądzenia zbrodni popełnionych przez Państwo Islamskie. Oba państwa, wyczerpane wojnami, próbując zaprowadzić sprawiedliwość, mimowolnie pogłębiają podziały i chaos. W Iraku specjalne sądy posługujące się prawem antyterrorystycznym w pośpiechu wydają surowe wyroki, nie dbając o zachowanie praw oskarżonych i nie różnicując ich winy. Powszechne jest stosowanie kary śmierci nawet za najdrobniejszą współpracę z terrorystami. Ponadto, jak zaznacza Nadim Houry, dyrektor programu ds. terroryzmu i antyterroryzmu Human Rights Watch (HRW), stworzenie przez ISIS struktur organizacyjnych na terytorium obu tych państw powoduje, że likwidacja skutków wymaga ich ścisłej współpracy w przestrzeni wymiaru sprawiedliwości, co z powodu olbrzymich różnic w ich systemach prawnych jest bardzo utrudnione ${ }^{57}$.

57 Houry 2017. 
W takim wypadku słusznym wydaje się wniosek, że na zasadzie komplementarności odpowiedzialność za ukaranie sprawców zgodnie z zasadą jurysdykcji uniwersalnej ciąży na wspólnocie międzynarodowej. Zasadę tę należy rozumieć jako ,(...) upoważnienie wszystkich podmiotów prawa międzynarodowego do podejmowania czynności zmierzających do osądzenia oraz, jeżeli taki będzie wynik postępowania, do ukarania sprawcy najcięższych zbrodni w świetle prawa międzynarodowego, niezależnie od tego, kim jest sprawca i jego ofiary oraz gdzie została popełniona zbrodnia" ${ }^{58}$. Nieodzowne wydaje się zaangażowanie międzynarodowe pod auspicjami ONZ i propozycja utworzenie międzynarodowego trybunału karnego. Teoretycznie na podstawie art. 12 ust 3 Statutu Rzymskiego Irak i Syria mogą uznać jurysdykcję Międzynarodowego Trybunału Karnego w odniesieniu do zbrodni popełnionych przez Państwo Islamskie. Podobna sytuacja nie miała jeszcze jednak miejsca.

Dla uporządkowania rozważań należy wskazać, że w praktyce możemy wyróżnić trzy rodzaje międzynarodowych trybunałów karnych:

1. Trybunał stały - powołany do istnienia przez poszczególne państwa na mocy umowy międzynarodowej. Do tej pory jedynym takim organem jest powołany na mocy Statutu rzymskiego z 1998 roku Międzynarodowy Trybunał Karny z siedzibą w Hadze.

2. Trybunał ad hoc - powoływany każdorazowo na mocy rezolucji Rady Bezpieczeństwa ONZ dla osądzenia osób fizycznych oskarżonych o popełnienie zbrodni międzynarodowych.

3. Trybunał hybrydowy (zwany również umiędzynarodowionym) powoływany na mocy umowy międzynarodowej pomiędzy ONZ a rządem państwa (w naszym przypadku dwóch państw - Iraku i Syryjskiej Republiki Arabskiej), który w swojej działalności łączy krajowe i międzynarodowe elementy wymiaru sprawiedliwości. Przykładem takiego trybunału może być Specjalny Trybunał dla Sierra Leone (przewaga elementu międzynarodowego), czy Specjalne Trybunały Kambodżańskie (przewaga elementu krajowego) ${ }^{59}$.

Skomplikowana sytuacja międzynarodowa Syrii oraz wyczulenie na punkcie suwerenności Iraku uniemożliwiają zasadniczo powołanie i sku-

58 Jeżewski 2003, 161; Izydorczyk 2008, 242-253.

59 Heidrich 2013, 160-161; Wiliński 2008, 65-66. 
teczne funkcjonowanie międzynarodowego trybunału karnego ad hoc. Oba państwa nie są również stronami Statutu Rzymskiego, dlatego nie podlegają jurysdykcji stałego Międzynarodowego Trybunału Karnego. Jedynym rozwiązaniem wydaje się powołanie trybunału hybrydowego. W obecnej skomplikowanej światowej sytuacji politycznej taka inicjatywa byłaby trudna do przeforsowania, a jeszcze trudniejsza w realizacji. Dodatkowo, jak już wspominaliśmy, Irak przeszedł w swojej niedawnej historii nie do końca udaną próbę stworzenia hybrydowego trybunału dla ukarania decydentów reżimu Saddama Husajna. Pierwotnym pomysłem było utworzenie międzynarodowego trybunału ad hoc. Ostatecznie amerykańskie władze okupacyjne powierzyły utworzenie trybunału sądownictwu irackiemu. Amerykanie obawiali się, że każdy sąd międzynarodowy zostanie odebrany przez iracką opinię publiczną jako sąd amerykański. Utworzenie organu krajowego nie ustrzegło jednak nowych władz irackich przed oskarżeniami o próbę przypodobania się okupantom. Element międzynarodowy mieli zapewnić zagraniczni konsultanci ${ }^{60}$.

Pomimo tego niepowodzenia wydaje się jednak, że to jedyna szansa na wymierzenie sprawiedliwości sprawcom i uczczenie pamięci ofiar ostatniego prześladowania mniejszości religijnych na Bliskim Wschodzie, a dla narodów syryjskiego i irackiego na przynajmniej częściowe wewnętrzne pojednanie.

\section{ZAKOŃCZENIE}

Uznanie prawa do wolności religijnej za jedno z podstawowych praw człowieka rodzi obowiązek sprawującego pieczę nad wspólnotą polityczną, czy to na poziomie narodowym, czy ponad narodowym, do zapewnienia każdemu możliwości realizacji tego prawa. Prześladowanie prawie zawsze dotyka mniejszości. Jednakże w przypadku wielkich religii takich jak chrześcijaństwo, islam czy judaizm akty nietolerancji na tle wyznaniowym powodują zazwyczaj reakcję opinii publicznej i realne wsparcie współwyznawców. Inaczej jest z wyznawcami religii niszowych. Ich przedstawiciele do tej pory cierpieli i umierali w milczeniu. Wydaje się, że reakcja na ostatnie ludobójstwo jezydów wreszcie zmienia tę sytuację. Ważne, aby

60 Zob. Grzebyk 2007, 371-389. 
za nagłośnieniem medialnym i deklaracjami politycznymi poszły czyny, które pozwolą na realne wymierzenie sprawiedliwości sprawcom, a także chociażby symboliczną rekompensatę i realne polepszenie losu ofiar.

W 2018 roku przypada siedemdziesiąta rocznica uchwalenia Powszechnej Deklaracji Praw Człowieka. Niepokojącym jest fakt, że w wielu miejscach świata wolność praktykowania religii jest jeszcze bardziej zagrożona niż w momencie uchwalania deklaracji. Rocznica ta może stanowić dobry pretekst do ponownego przeanalizowania przyczyn i próby zmiany takiego stanu rzeczy. Pomocnym instrumentem, który ułatwiłby reakcję na wszelkie akty nietolerancji religijnej na świecie byłaby konwencja międzynarodowa gwarantująca wolność wyznania. Konwencje ONZ objęły przecież tak szeroki zakres spraw jak prawa kobiet i dzieci, osób niepełnosprawnych, migrantów, kwestie tortur, uprowadzeń czy dyskryminacji ze względu na rasę $^{61}$. Państwa zrzeszone w ONZ bezskutecznie próbowały wypracować tekst konwencji o wyeliminowaniu wszelkich form nietolerancji religijnej. Starania te zwieńczyło jedynie przyjęcie w 1981 roku przez Zgromadzenie Ogólne ONZ Deklaracji w sprawie eliminacji wszelkich form nietolerancji i dyskryminacji opartych na religii lub przekonaniach (Rezolucja Zgromadzenia Ogólnego ONZ z dnia 25 listopada 1981, A/RES/36/55), której wymowa została osłabiona przez kraje Organizacji Konferencji Islamskiej ${ }^{62}$. Sytuację taką należy uznać za ze wszech miar niezadowalającą.

\section{BIBLIOGRAFIA}

Allison, Christine. 2004. „Yazidis i. General”. Encyclopcedia Iranica, online edition. http://www.iranicaonline.org/articles/yazidis-i-general-1 [dostęp: 6.12.2017].

Al-Midani, Mohammed Amin, Mathilde Cabanettes, Susan M. Akram. 2006. „Arab Charter on Human Rights 2004”. Boston University International Law Journal 2: 147-164.

Al-Waqa'i Al-Iraqiya. 2005. "Law of the Supreme Iraqi Criminal Tribunal". AlWaqa'i Al-Iraqiya, przekł. The International Center for Transitional Justice. 18 października 2005. http://gjpi.org/wp-content/uploads/2009/02/iraqstatuteengtrans.pdf [dostęp: 22.12.2017].

61 Cox 2015, 53-54.

62 Bar 2003, 77-86. 
Asatrian, Garnik S.,Victoria Arakelova. 2014. The Religion of the Peacock Angel. The Yezidis and their Spirit World. London - New York: Routlege.

Bałon, Krzysztof. 2004. „Iracki Trybunał Nadzwyczajny do spraw Zbrodni przeciwko Ludzkości”. Biuletyn Polskiego Instytutu spraw Międzynarodowych 12: 1089-1091.

Bania, Radosław. 2016. „Powstanie tzw. Państwa Islamskiego w Iraku”. W: Problemy bezpieczeństwa Bliskiego Wschodu i Pótnocnej Afryki (MENA), red. Radosław Bania, Robert Czulda, Krzysztof Zdulski. 13-29. Łódź: Wydawnictwo Uniwersytetu Łódzkiego.

Bar, Wiesław. 2003. Wolność religijna w Dār al-Islām. Zagadnienia prawa wyznaniowego. Lublin: Wydawnictwo Polihymnia Sp. z o.o.

Confédération suisse. Département fédéral des affaires étrangères. Traités internationaux pour lesquels la Suisse assume les fonctions de dépositaire. Conventions de Genève pour la protection des victimes de la guerre: Convention relative à la protection des personnes civiles en temps de guerre faites à Genève le 12 août 1949 entrées en vigueur le 21 octobre 1950 ( 2 ratifications). https:// www.eda.admin.ch/dam/eda/fr/documents/aussenpolitik/voelkerrecht/geneve/1949-conv-4-parties_fr.pdf [dostęp: 22.12.2017].

Cox, Caroline. 2015. „Wolność religijna: prawo osierocone”. W: Czarna księga prześladowań chrześcijan w świecie, red. Jean-Michele di Falco, Timothy Radcliffe, Andrea Riccardi, przekł. Bogdan Baran. 51-68. Poznań: Dom Wydawniczy REBIS.

Dabiq. 2014. "The Revival of Slavery Before the Hour". Dabiq 4: 14-17.

Grzebyk, Patrycja. 2007, „Iracki Trybunał Nadzwyczajny - nieudana hybryda”. Rocznik Strategiczny 2006/2007. Przeglad sytuacji politycznej, gospodarczej $i$ wojskowej $w$ środowisku międzynarodowym Polski, red. Roman Kuźniar, 371-389. Warszawa: Wydawnictwo Naukowe Scholar.

Hanne, Olivier, Thomas Flichy de la Neuville. 2015. Państwo Islamskie. Geneza nowego kalifatu, przekł. Janusz Danecki. Warszawa: Wydawnictwo Akademickie DIALOG.

Heidrich, Dorota. 2013. „Przyszłość międzynarodowych trybunałów karnych ad hoc". Studia Europejskie 3: 159-182.

Houry, Nadim. 2017. Justice after ISIS: time for judicial triage. 25 sierpnia 2017. https://www.opendemocracy.net/north-africa-west-asia/nadim-houry/justice-after-isis-time-for-judicial-triage [dostęp: 15.12.2017].

Human Right Watch (HRW). 2017. Flawed Justice. Accountability for ISIS Crimes in Iraq. 5 grudnia 2017. https://www.hrw.org/report/2017/12/05/flawed-justice/accountability-isis-crimes-iraq [dostęp: 15.12.2017]. 
Izydorczyk, Jacek. 2008a. „Jurysdykcja uniwersalna oraz zasada komplementarności". W: Podstawy prawa karnego międzynarodowego, red. Michał Królikowski, Paweł Wiliński, Jacek Izydorczyk. 242-261. Warszawa: Wolters Kluwer Polska Sp. z o.o.

Izydorczyk, Jacek. 2008b. „Zbrodnie międzynarodowe”. W: Podstawy prawa karnego międzynarodowego, red. Michał Królikowski, Paweł Wiliński, Jacek Izydorczyk, 113-149, Warszawa: Wolters Kluwer Polska Sp. z o.o.

Jeżewski, Marek. 2003. „Uniwersalna jurysdykcja karna w prawie międzynarodowym”. Kwartalnik Prawa Publicznego 3(2): 159-178.

Kaczorowski, Karol. 2015. Religie Kurdów. Jezydyzm, ahl-e haqq, alewizm. Katowice: Wydawnictwo Sacrum.

Kikoler, Naomi. 2015. „Our Generation is Gone”. The Islamic State's Targeting of Iraqi Minorities in Ninewa. Bearing Witness Trip Report. Washington: Simon-Skjodt Center for the Prevention of Genocide, The United States Holocaust Memorial Museum. https://www.ushmm.org/m/pdfs/Iraq-Bearing-Witness-Report-111215.pdf [dostęp: 11.12.2017].

Koran. 1986. Przekł. Józef Bielawski. Warszawa: Państwowy Instytut Wydawniczy. Kreyenbroek, Philip G., Khalil Jindy Rashow. 2005. God and Sheikh Adi are Perfect. Sacred Poems and Religious Narratives from Yezidi Tradition. Wiesbaden: Harrassowitz Verlag.

Kreyenbroek, Philip G. 2009. Yezidism in Europe. Different Generations Speak about their Religion. Wiesbaden: Harrassowitz Verlag.

Kreyenbroek, Philip G. 1995. Yezidism - Its Background, Observances and Textual Tradition. Lewinston - Queenston - Lampeter: The Edwin Mellen Press.

Królikowski, Michał. 2011. Odpowiedzialność karna jednostki za sprawstwo zbrodni międzynarodowej. Warszawa: Wydawnictwo Sejmowe.

Królikowski, Michał. 2008. „Źródła i stosowanie prawa karnego międzynarodowego". W: Podstawy prawa karnego międzynarodowego, red. Michał Królikowski, Paweł Wiliński, Jacek Izydorczyk. 73-98. Warszawa: Wolters Kluwer Polska Sp. z o.o.

Maisel, Sebastian. 2014. Sectarian-Based Violence: The Case of the Yezidis in Iraq and Syria. Middle East Institute. 23 lipca 2014. http://www.mei.edu/content/ map/sectarian-based-violence-case-yezidis-iraq-and-syria [dostęp: 11.12.2017].

Maisel, Sebastian. 2008. „Social Change Amidst Terror and Discrimination: Yezidis in the New Iraq". The Middle East Institute Policy Brief 18: 1-9. https://www.mei.edu/sites/default/files/publications/Maisel_CS3_latest.pdf [dostęp: 6.12.2017].

Omarkhali, Khanna. 2014. „Current Changes in the Yezidi System of Transmission of Religious Knowledge and the Status of Spiritual Authority". W: Religious 
Minorities in Kurdistan: Beyond the Mainstream, red. Khanna Omarkhali. 6777. Wiesbaden: Harrassowitz Verlag.

Refworld. http://www.refworld.org/docid/452524304.html [dostęp:15.12.2017].

Rodziewicz, Artur. 2017. „Odrodzenie religii jezydzkiej w Gruzji. Rozmowy z Dimitrijem Pirbarim, głową Duchowej Rady Jezydów w Gruzji”. Fritillaria Kurdica. Bulletin of Kurdish Studies 3: 4-67.

Samir, Samir Khalil, Giorgio Paolucci, Camille Eid. 2004. Islam. Sto pytań, przekł. Karol Klauza. Warszawa: Instytut Wydawniczy Pax.

The University of Utah. S. J. Quinney College of Law. Global Justice Project: Iraq, http://gipi.org/library/primary/kurdistan-region-legislation/ [dostęp: 15.12.2017].

Thoraval, Yves. 2002. „Ludzie Księgi”. W: Słownik cywilizacji muzułmańskiej, Yves Thoraval, przekł. Paweł Latko. 166-167. Katowice: Wydawnictwo „Książnica”.

United Nations High Commissioner for Human Rights. 2015. Report of the Office of the United Nations High Commissioner for Human Rights on the human rights situation in Iraq in the light of abuses committed by the so-called Islamic State in Iraq and the Levant and associated groups. A/HRC/28/18. 13 marca 2015. http://www.ohchr.org/EN/HRBodies/HRC/.../A_HRC_28_18_AUV. doc [dostęp: 13.12.2017].

United Nations Human Rights Council. 2016. ,, They came to destroy”: ISIS Crimes Against the Yazidis. A/HRC/32/CRP.2. 15 czerwca 2016. http://www.ohchr. org/Documents/HRBodies/HRCouncil/CoISyria/A_HRC_32_CRP.2_en.pdf [dostęp: 13.12.2017].

Vertic. http://www.vertic.org/media/National\%20Legislation/Iraq/IQ_Anti-Terrorism_Law.pdf [dostęp: 15.12.2017].

Wiliński, Paweł. 2008 „Typy, geneza i działalność międzynarodowych trybunałów karnych". W: Podstawy prawa karnego międzynarodowego, red. Michał Królikowski, Paweł Wiliński, Jacek Izydorczyk. 50-72. Warszawa: Wolters Kluwer Polska Sp. z o.o.

Wojciechowski, Sebastian, 2016. „Fenomen «Państwa Islamskiego» i jego źródła”. Przeglad Strategiczny 1: 143-155. 


\section{RELIGIOUS PERSECUTION OF THE IRAQI YEZIDIS \\ BY THE ISLAMIC STATE. THE REASONS, COURSE \\ AND RESPONSIBILITY OF THE INTERNATIONAL COMMUNITY FOR THE PUNISHMENT OF THE PERPETRATORS}

\section{Summary}

The aim of this paper is to discuss the persecution of the Iraqi Yezidis by the socalled Islamic State of Iraq and Syria that took place over the last years, to present its political and religious background, and to analyse its legal consequences, which includes the possibility of punishing the perpetrators under international law. The article consists of three main parts: The first one gives a short account of the history and theology of Yezidism; the second part presents the origin and course of the religious persecution of the Yezidis; and the third part suggests some legal actions that could be undertaken by the international community with a view to punishing the perpetrators. The final section of this paper proposes the establishment of an international criminal court as an alternative solution to solve the problem of how perpetrators should be punished in such cases.

Key words: religious freedom; persecution of the Yezidis; genocide; Islamic State; ISIS; Yezidism; criminal responsibility; international criminal court 